\title{
Hot Kitchens in Places of Quiet Beauty: Iowa State Parks and the Transformation of Conservation Goals
}

\author{
REBECCA CONARD
}

WHILE MILO RENO was making political headlines with the farm revolt in 1931, the Iowa General Assembly paused momentarily, turned its attention from farm problems and economic depression, and took a bold step toward resource conservation planning. ${ }^{1}$ In March of that year, legislators authorized the State Board of Conservation and the State Fish and Game Commission to prepare a long-range, comprehensive plan for conservation. That plan, completed in 1933, meshed with emerging ideas and programs at the federal level as part of President Franklin Roosevelt's New Deal. It was not, however, a reaction to federal policies. The idea of a state conservation plan was bred, if not born, in Iowa's fledgling state park system. It culminated a decade of combined efforts to create and administer what, by 1931, was one of the largest state park collections in the United States. As public demand for state recrea-

Earlier versions of this essay were delivered as papers at the 1991 Congress of Historical Organizations, June 8, 1991 at Des Moines, and the National Council on Public History annual meeting, March 14, 1992 at Columbia, South Carolina. The initial research for this article was conducted for the State Historical Society of Iowa, with grant support under the National Historic Preservation Act of 1966, as amended, from the U.S. Department of the Interior. I would like to thank Lowell Soike and Susan Flader for their helpful comments during the revision process.

1. On Milo Reno and the farm revolt, see Joseph Frazier Wall, Iowa: A History (New York, 1978), 176-78; John Shover, Cornbelt Rebellion: The Farmers' Holiday Association (Urbana, IL, 1969); and Theodore Saloutos and John D. Hicks, "The Farm Strike," in Patterns and Perspectives in Iowa History, ed. Dorothy Schwieder (Ames, 1973), 359-77.

THE ANNALS OF IOWA 51 (Summer 1992). CThe State Historical Society of Iowa, 1992. 
tion facilities grew, it became clear that state parks could no longer meet the broad scope of their original purpose, which was to serve as a means "for the preservation of beautiful places, for the protection of wild life, for the enrichment of the landscape, and for active recreation." ${ }^{2}$

In the process of establishing the park system and coming to grips with the realities imposed by public access and use, conservation goals were altered in ways that early visionaries of the state park system found disturbing. As the state conservation plan study progressed, the Board of Conservation, which administered Iowa's state parks, also began to envision how the parks might be improved to accommodate rapidly increasing numbers of visitors. Considerable discussion appears to have centered on Backbone State Park, because in 1932 state landscape architect John Fitzsimmons prepared an elaborate conceptual landscaping plan for that park. It depicted multiple camping and picnic areas, a large nature study complex, and a network of roads and trails. Fitzsimmons then sent the plan to Thomas Macbride, who by then was the aging dean of conservation in Iowa, and asked for his comments. ${ }^{3}$

In his return letter, Macbride opened with two pages of anecdotal introduction recalling the extraordinary effort it had taken to arouse public and political interest in a park system, then pass the state legislation that enabled conservationists to bring the Backbone under state ownership. With that preface he continued, "I see that at the north end the 'Little Backbone,' as it used to be called, was chosen as one of the places where people might go to hold a picnic dinner, if I read the symbols aright, and that the larger 'Backbone' is marked out in a similar

2. Jacob L. Crane, Jr., and George Wheeler Olcott, Report on the Iowa TwentyFive Year Conservation Plan (Des Moines, 1933), 2-3.

3. Macbride was professor of botany at the State University of Iowa from 1878 until he retired in 1916 . He is most widely known as University of Iowa president from 1914 to 1916 and as the force behind Iowa Lakeside Laboratory, founded in 1909. See Debby J. Zieglowsky, "Thomas Macbride's Dream: Iowa Lakeside Laboratory," Palimpsest 66 (1985), 42-65. Following his retirement, he and his wife moved to Seattle. Although they never returned to Iowa as permanent residents, Macbride maintained an active interest in conservation activities and issues affecting Iowa as evidenced by correspondence with his former colleagues. 
way. Is all the quiet beauty of our park, like Mt. Rainier at Seattle, simply a hot kitchen ... where we get chicken dinner?"4 Macbride fired back a similar volley when Fitzsimmons sent him a copy of the "Conservation Program in Our State Parks." "I am frightened when you talk of landscape-development. For the wild things, the birds and trees, we fain would save from threatened absolute destruction, Nature's landscape is exactly right. The wild woods and thickets undisturbed, grasses, sedges, composites, hazels, cedars are precisely right. To these we can add nothing. ${ }^{\text {"5 }}$ Macbride's outpourings represented more than a clash of egos. They signified a major shift in fundamental concepts underlying the mission of Iowa's state park system between the late 1890s, when state parks were just a hazy dream, and the early 1930s, when Iowa embarked on a program that would define the park system we recognize today.

BY MANY ACCOUNTS, the Iowa state park system was conceptualized in 1895 when Macbride tried to inspire "an effort to call back into public favor the once familiar public 'common.'" Speaking before his colleagues in the Iowa Academy of Sciences, Macbride described his idea for a statewide system of county, or rural, parks - the terms were used interchangeably at the time. That address and Macbride's call for forest reservations two years later, in 1897, are often cited as the beginning of the conservation movement in Iowa. ${ }^{6}$ It was a movement that had many facets: some were focused on wildlife propagation, some on forest regeneration, some on preserving native flora. Central to the history of conservation in Iowa, however, was the creation and evolution of the state park system, particularly through the 1920s and 1930s.

4. Macbride to Fitzsimmons, 7 February 1933, Thomas H. Macbride Papers, University of Iowa Archives, Iowa City. During the late 1920s, there was considerable debate in Washington state over how much development should be allowed in Mt. Rainier National Park. Macbride obviously followed the debate and had a strong opinion about the outcome.

5. Macbride to Fitzsimmons, undated copy of letter [1932], Macbride Papers; emphasis in the original.

6. T. H. Macbride, "County Parks," Proceedings of the Iowa Academy of Sciences 3 (1895), 91; Thomas H. Macbride, "The President's Address," ibid. 5 (1897), 17-23. 
Iowa was not among the first states to establish state parks, but as the movement gained momentum, it took a leading position. Nationwide, the first phase of what would become a state parks movement took place between 1864 and 1895, when five states set aside parks to preserve areas of outstanding natural beauty or with important historical associations. The federal government ceded Yosemite Valley and Mariposa Grove to the state of California for a state park in 1864 . Twenty years later, in a similar move, the federal government transferred Mackinac Island, a former military reservation, to the state of Michigan for development into a state historical park. In 1883 the New York legislature authorized a reservation of land "to preserve the scenery of the Falls of Niagara." Two years later New York authorized Adirondack State Forest. Between 1889 and 1895, Minnesota established three state parks to protect scenic and historic areas: Itasca, Birch Coulee, and Camp Release. Itasca preserved the headwaters of the Mississippi River; the latter two commemorated Indian-white battlegrounds. In $1895 \mathrm{New}$ York and New Jersey jointly acquired the nucleus of Palisades Interstate Park, the first state park created purely for recreational purposes. ${ }^{7}$ These isolated events prefigured more widespread activity in the early twentieth century.

A number of interrelated concerns drove state park advocates. In the Pacific Northwest, protecting natural scenery and roadside timber from logging fueled the state parks movement in Oregon and Washington. Similarly, California's movement evolved from the campaign to save the redwoods. Richard Lieber's vision of preserving scenic areas as retreats for the urban working class and as pristine snatches of the past for future generations gave rise to Indiana's state park system, launched in 1916. Forestry conservation, as opposed to scenic

7. In 1905 California returned the land to the national government for inclusion in Yosemite National Park, but for thirty years the valley and nearby Mariposa Grove remained a state park. See Joseph H. Engbeck, Jr., and Philip Hyde, State Parks of California from 1864 to the Present (Portland, 1980), 17-28; Natural Heritage Trust, Fifty Years: New York State Parks, 1924-1974 (Albany, NY, 1975); Beatrice Ward Nelson, State Recreation: Parks, Forests and Game Reservations (Washington, DC, 1928), 3-5; Roy W. Meyer, Everyone's Country Estate: A History of Minnesota's State Parks (St. Paul, 1991), $1-22$. 
preservation, figured more prominently in the state park movements in New York and Wisconsin. Depredations on the timber in the Adirondack State Forest, set aside in 1885, gave rise to the Adirondack Park Association and passage of state legislation authorizing New York's state park system in 1890. The Adirondacks belatedly inspired Wisconsin's state park system. In 1876 the Wisconsin state legislature set aside fifty thousand timbered acres in Lincoln County, which became known as "The State Park." Twenty-one years later, in 1897, the legislature released the park for sale to lumber companies. That action prompted a new effort, which led to land acquisition along the St. Croix River in what is now Interstate Park. By 1915, state parks, state forests, and fish and wildlife protection were jointly administered in Wisconsin by a coordinated State Conservation Commission. The tie that bound state park advocates, who often were widely separated by geography and sometimes unaware of activities outside their own states, was political progressivism, that is, positive state intervention to improve society. ${ }^{8}$

Although Iowa had no vast woodlands or spectacular ancient trees, forest conservation nonetheless sparked its state parks movement. Louis H. Pammel, head of the botany department at Iowa State College and an academic colleague of Thomas Macbride, gave notice in the state's major newspapers that on November 16, 1901, he would convene a meeting of those persons who wished "to encourage the growth of a wholesome interest in forestry, looking to the care, preservation and reproduction of our commercial trees." Promoting scientific forest management seems to have been Pammel's original motive, but it quickly got mixed in with promoting parks. The

8. Thomas R. Cox, The Park Builders: A History of State Parks in the Pacific Northwest (Seattle, 1988), especially chap. 3, "Ben Olcott's Crusade to Save Oregon's Scenery," 32-46, and chap. 5, "Asahel Curtis, Herbert Evison, and the Parks and Roadside Timber of Washington State," 57-78; Engbeck and Hyde, State Parks of California, 29-56; Glory-June Greiff, "New Deal Resources in Indiana State Parks," NRHP Multiple Property Documentation Form, July 1991; Eugene James O'Neill, “Parks and Forest Conservation in New York, 1850-1920" (Ph.D. diss., Columbia University, 1963), especially chap. 4, "The Rise of a Separate Park Movement," 96-113; Wisconsin State Planning Board and Wisconsin Conservation Commission, A Park, Parkway and Recreational Area Plan (Madison, 1939), 33-36. 
initial meeting was well attended, and, although no record of the discussion seems to have survived, those in attendance no doubt shaped the organization born that night. In any case, the organization founded a few weeks later was known as the Iowa Park and Forestry Association (IPFA), revealing its dual focus. Speaking at the IPFA's first annual meeting, on December 10 and 11, 1901, C. A. Mosier of Des Moines urged the "necessity of establishing as soon as possible, one or more state parks embracing within their boundaries large bodies of water and groves of native timber." The constitution adopted at that meeting clearly reflected the degree to which IPFA founders saw the establishment of rural parks and forest reserves as part and parcel of wildlife, lake, and stream conservation. Article II listed the association's purposes as being:

to create an interest in, and to encourage the establishment of parks;

the beautifying of our cities, the better care of cemeteries, the planting of trees in country homes for aesthetic purposes as well as for the supply of timber for commerce;

the proper utilization of our remaining timber, and to assist in the inauguration of rational methods of forest management and thus help in the protection of our wild game and song birds;

the creation of one or more state parks in the vicinity of our lakes and streams;

to encourage state and national legislation for rational forest management, and the creation of more forest reserves. ${ }^{9}$

The next step toward a state park movement came in 1902 when Thomas Macbride circulated a questionnaire concerning the status of parks in the state. Out of 150 replies, he found that all but six towns maintained some type of park space. Seventy of the parks, however, were "the old fashioned square in the middle of the town," most of them being the public grounds

9. Louis H. Pammel, "Park Movement in the State," undated typescript [c. 1918], Louis H. Pammel Papers, Iowa State University; C. A. Mosier, "Our Objects and Aims," Proceedings of the Iowa Park and Forestry Association 1 (1901), 12; "Constitution and By-Laws," ibid., 4-5. 
surrounding courthouses. Macbride was truly chagrined to learn, though, that cemeteries often doubled as parks. ${ }^{10}$ Armed with that information, the association appealed to the state legislature to create a state park around the capitol in Des Moines. The effort failed, and so did another to authorize townships and counties to purchase land for parks. ${ }^{11}$ In 1905 botanist Bohumil Shimek proposed that the Secor Forestry Bill, which the IPFA sponsored, be amended to expand the powers of the State Geological Board. His idea, which was radical for the time, would have authorized the board to survey and "take up" denuded lands, place them under the jurisdiction of a State Forest, Fish, and Game Warden, and restore them for use as rural parks. ${ }^{12}$ However politically infeasible Shimek's proposal may have been at the time, it presaged the State Conservation Commission, which emerged in 1935 with coordinated jurisdiction over all natural resources in the state. As it was, the Forest and Fruit Tree Reservation Act passed in 1906 with no such amendment, providing instead limited property tax relief for landowners who planted trees or protected timbered areas. ${ }^{13}$

Forest conservation precipitated agitation for state parks, but eventually the movement crystallized around the issue of Iowa's lakes. As early as 1896, the Iowa Academy of Sciences appealed to the legislature to protect lakes "in order to maintain some of the original conditions of the state" and to develop them into "pleasure resorts" for the citizens of Iowa. In 1910 Macbride and Bohumil Shimek, his colleague in the botany department at the university, participated in preparing a report for the Iowa State Drainage Waterways and Conservation Commission urging that Iowa place its lakes under the jurisdiction of

10. Thomas H. Macbride, "President's Address: The Present Status of Iowa Parks," Proceedings of the Iowa Park and Forestry Association 2 (1902), 6-7.

11. Thomas P. Christensen, "The State Parks of Iowa," Iowa Journal of History and Politics 26 (1928), 339-40.

12. Bohumil Shimek, "Township, County, and State Parks," Proceedings of the Iowa Park and Forestry Association 5 (1905), 18-19.

13. The Forest and Fruit Tree Reservation Act of 1906, also known as the Secor Forestry Act or the Bixby Forestry Act, provided that lands occupied by woodlots, groves, and orchards of specified minimum size and containing certain listed trees be given a taxable value of one dollar per acre if the landowner complied with certain conditions. Laws of Iowa, 1906, chap. 52, pp. 35-37. 
a custodial agency in order to stop the dwindling of these public waters. ${ }^{14}$

The legislature finally acted in 1915 , passing a law that directed the State Highway Commission to coordinate a study of seventy lakes to which the state still held sovereign title. The original plats of the U.S. Land Survey showed 109 meandered lakes in Iowa, covering approximately 61,000 acres. Under the provisions of an 1850 federal law granting swampland grants to certain states, including Iowa, some of these lakes were reclassified as swampland and subsequently sold. Then, in 1913 the state authorized the sale of abandoned river channels, which affected a handful of lakes along the Mississippi and Missouri rivers. Because the remaining seventy lakes were surrounded by privately owned land, many had been subjected to repeated encroachment. The line of meander-that is, the line between public and private ownership-was a vague concept to most people. In practice, it generally meant the high-water mark, but since the state had no agency watching over its public waters, private landowners along lake shores could, with impunity, drain shallower lakes and inch their fields toward the shrinking line of meander. ${ }^{15}$

The purpose of the lake study was to determine which of the seventy remaining lakes should be retained and maintained, which should be drained, and which should be sold. Over a two-year period, the Highway Commission, assisted by the State Fish and Game Warden and professors from Iowa State College, conducted surveys and studies that yielded detailed topographic maps covering approximately ninety thousand acres, individual lake studies, and reports on crop surveys near various lakes, the vegetation of Iowa lakes, and the potential for improving lake shores through forestation. This marked the first time in the history of the state that its public lands had ever been studied for conservation purposes. When

14. Memorial to the Twenty-sixth General Assembly from the Iowa Academy of Science, drafted by T. H. Macbride, L. H. Pammel, and B. Fink, reported in Proceedings of the Iowa Academy of Sciences 3 (1895), 15; Christensen, "The State Parks of Iowa," 340-41.

15. Report of the State Highway Commission for 1916, Supplementary Report, Iowa Lakes and Lake Beds (Des Moines, 1917), 9. See also Roscoe L. Lokken, Iowa Public Land Disposal (Iowa City, 1942), 180-209. 
the Highway Commission reported its findings in 1917, it recommended that the state retain its existing lakes and "adopt an intelligent policy of betterment," whatever that meant. ${ }^{16}$

Conservationists played a key role in determining just what a "policy of betterment" would be. In 1914 the IPFA had changed its name to the Iowa Forestry and Conservation Association (IFCA), a change that subtly indicates how little had been accomplished with respect to parks. The lake study, however, revived hopes for a state park system. As one measure of this, the IFCA began publishing a quarterly, Iowa Conservation, in 1917. In the first issue, Bohumil Shimek published a list of one hundred areas that he thought would make suitable parks. The vast majority of sites on the list were lakes and areas adjacent to rivers. Fifteen sites were especially desirable, he felt, as areas that could serve the combined functions of recreation, game preservation, and plant preservation. A year later, in 1918, the IFCA dropped "forestry" from its name and became the Iowa Conservation Association (ICA). ${ }^{17}$

The Iowa Federation of Women's Clubs (IFWC) also played an important role in the success of the state parks movement. There is a certain irony in this since Thomas Macbride had once ruefully observed that "the effort for city and park improvement ha[d] fallen to the hands of the women." ${ }^{18}$ What Macbride initially saw as a weakness, however, others perceived as a potential strength. By 1907, women were actively participating in IPFA meetings. Participation increased slowly but steadily over the next several years while the organization went through a process of change. Then, in 1915, certain members of the Iowa Federation of Women's Clubs "discovered" the IFCA and sought to become involved. Chief among them was Cora Call Whitley, who organized the IFWC's first committee on the Conservation of Natural Scenery. The results were immediately apparent. At the IFCA's annual meeting in 1916, women presented eight out of thirty-four papers; several of those women also were highly visible in the Iowa Federation's conservation work. From that time forward, women participated in the Con-

16. Report, Iowa Lakes, 11-12.

17. B. Shimek, "Iowa's Natural Parks," Iowa Conservation 1 (1917), 16-17.

18. Macbride, "President's Address: Status of Iowa Parks," 9. 
servation Association's committee work, held office in the organization, and sat on the board of directors. Although the association remained male-dominated, its members were keenly aware that the IFWC was a powerful ally. The two organizations cooperated on the parks effort as well as other conservation causes. Louis Pammel's correspondence reveals that he cultivated such collaborative efforts. ${ }^{19}$

Nineteen hundred seventeen was a pivotal year. No doubt emboldened by the passage of the National Parks Service Act in 1916, key members of the Iowa Forestry and Conservation Association were more committed than ever to securing parks legislation. With the Thirty-seventh General Assembly in session, the IFCA met in Ames and decided it was time for Iowa to act. Seven individuals formed a special legislative committee, which, according to an account left by Pammel,

decided that it would be a good plan to meet with certain members of the legislature interested in preserving historic places in the state. ... This organization went over the situation as to what legislation was needed to make operative the suggestions of the Iowa Forestry and Conservation Association. Senator Holdoegel presented an outline of a bill he intended to introduce to the Senate on the matter of acquiring land for the fish and game warden and the improvements of lakes. It was decided to add to the bill a provision for the investigation of beauty spots and other places of historic interest, [and] the appointment of a commission, without pay, to organize the state and utilize the agencies of the state to make these investigations. ${ }^{20}$

19. The Proceedings of the Iowa Park and Forestry Association for 1907-1917 show the increasing participation of women in the programs. Cora Call Whitley to Pammel, 21 November 1915, and Pammel to Whitley, 23 November 1915, Pammel Papers, are but two of many letters in the file between Pammel and Whitley, and between Pammel and May McNider of Mason City, another IFWC member who became deeply involved in conservation work.

20. "Report of Executive Committee," typescript prepared by Louis $\mathrm{H}$. Pammel, n.d., Pammel Papers; see also L. H. Pammel, "The Park Movement in Iowa," undated typescript, Pammel Papers. The members of the committee were Louis Pammel; G. B. MacDonald, head of the forestry department at Iowa State College; C. F. Curtiss, dean of agriculture at Iowa State College and director of the Iowa Agricultural Experiment Station; Dr. James H. Lees, assistant state geologist; Bohumil Shimek, professor of botany at the Univer- 
Senator Holdoegel acted without delay, introducing the agreed-upon bill shortly thereafter. It quickly passed the Senate without dissent, then passed through the House on a sixtythree to twenty-five vote. On April 12, 1917, Governor William L. Harding signed the Holdoegel Act into law, authorizing the creation of a State Board of Conservation with power to acquire places of historic, natural, or recreational interest for the purpose of creating state parks. Within the state government's hierarchy, the board acted as an advisory body to the Executive Council, which, throughout the 1920s, routinely approved virtually all actions taken by the board. ${ }^{21}$

Not surprisingly, Governor Harding appointed Louis $\mathrm{H}$. Pammel to serve on the first State Board of Conservation, although Pammel himself supported other scientists for appointments. ${ }^{22}$ Also appointed to the first board were Fort

sity of Iowa; E. R. Harlan, curator of the State Historical Department; and Thomas H. MacDonald, professor of engineering at Iowa State College and engineer for the Iowa Highway Commission. They met with Senator Byron W. Newberry of Strawberry Point, Representative Orville Lee of Sac County, and Representative B. J. Horchem of Dubuque County in Senator Perry C. Holdoegel's quarters in the Hotel Savery (Holdoegel was chairman of the Senate Committee on Fish and Game).

21. Louis H. Pammel, "What the Legislature Did with Reference to State Parks in Iowa," Iowa Conservation 3 (1919), 14-15; Christensen, "The State Parks of Iowa," 345. The complete text of the state park law appears in Laws of Iowa, 1917, chap. 236, pp. 252-54, and is reprinted in Iowa State Parks Bulletin 1 (1923), 12-14. The Executive Council included the governor, state treasurer, state auditor, secretary of state, and secretary of agriculture. In some respects, calling the state park law the Holdoegel Act overstates the senator's role, for Holdoegel had just entered the legislature in 1917. His political inclinations and ambitions, therefore, were largely unknown to members of the IFCA, but because he was chair of the Senate Committee on Fish and Game, he was the logical choice to approach. Holdoegel turned out to be a good ally in the capitol until 1925, when he left office. There is no evidence that he was active in any activities of the conservation movement in Iowa prior to entering the legislature in 1917, but once Louis Pammel drew him into the fold, he solidly supported the creation of state parks. Holdoegel personally worked to establish Twin Lakes State Park in his own district, and when the park was created in 1923, he agreed to act as honorary custodian, in which capacity he worked to see that the park was landscaped, fenced, and improved with camping and picnicking facilities.

22. See, for instance, Pammel to E. R. Harlan, 22 September 1917, and Pammel to Senator P. C. Holdoegel, 16 October 1917, Pammel Papers, in which Pammel promoted C. F. Curtiss, dean of agriculture at Iowa State College; George Kay, state geologist and professor of geology at the State Uni- 


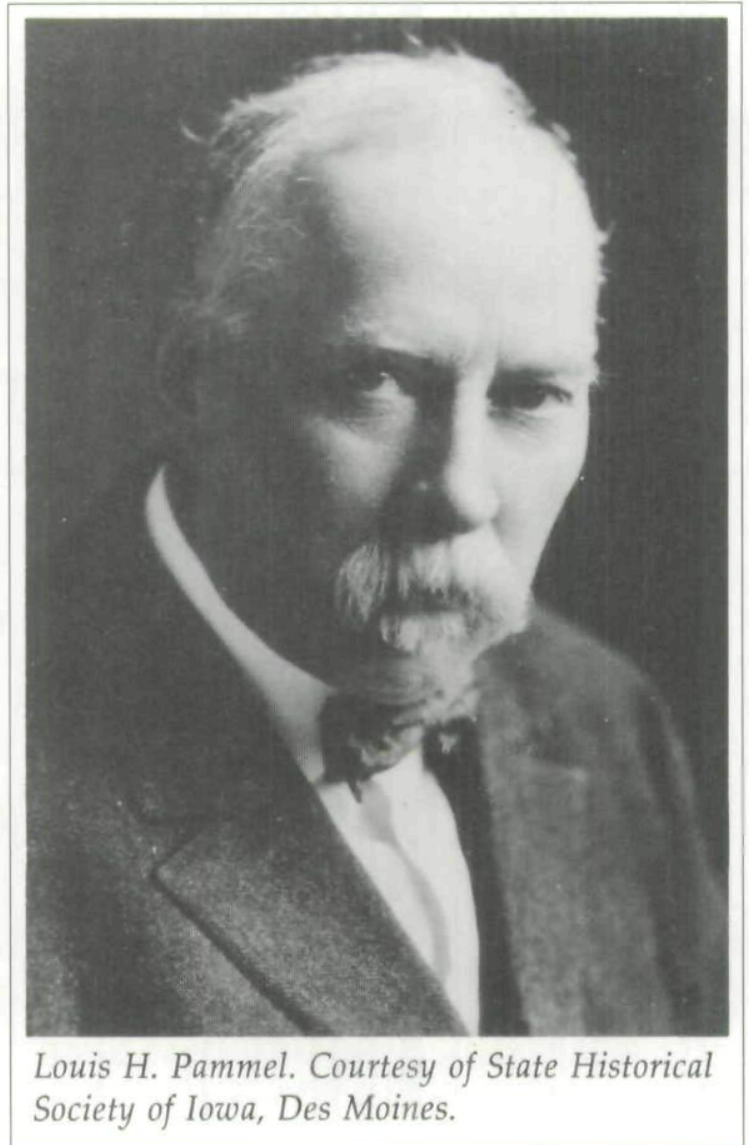

Dodge mayor John Ford and Bellevue banker Joseph Kelso. E. R. Harlan, curator of the State Historical Department, served as ex officio member and secretary of the board. Pammel's colleagues selected him as chairman, a position he used to great advantage until he retired from the board in 1927. Among other things, this position gave him some-though not unlimited-influence over future board appointments, and it was not long before conservationists affiliated with the Iowa Federation of Women's Clubs were seated on the board.

Scattered correspondence indicates that Pammel worked to secure board members who held conservation values similar to his own and who also had the means to devote the long

versity of Iowa; and archeologist Ellison Orr, then serving as president of the Iowa Conservation Association. 
hours of unpaid work that board responsibilities demanded. He was not always successful, as when he sought to include more scientists like himself on the board, and when he tried to persuade Governor Kendall that a board made up of representatives from the University of Iowa, Iowa State College, the State Horticulture Department, and the Executive Council would "bring the various organizations into harmony by asking them for a more cooperative working plan." 23

Women of means within the IFWC who had proved themselves to be dedicated allies in the past were perfect choices. May McNider of Mason City, chair of the IFWC's Conservation Committee and former vice-president of the Iowa Conservation Association, was appointed to the board in the early 1920s. In 1923 Governor Kendall expanded the board to five members and appointed Mary Armstrong of Fort Dodge, who was also active in IFWC circles, to fill the new post. When May McNider decided to give up her seat in 1926, the IFWC backed Margo Frankel of Des Moines as her replacement. All three women had proved themselves as activists within the IFWC, while their status as wives of prominent businessmen provided the time and financial independence they needed to engage in the unpaid work of the board. The relationship between the IFWC and conservation work bears closer scrutiny, but McNider, Armstrong, and Frankel all proved to be intelligent choices. ${ }^{24}$

23. Pammel to Gov. N. E. Kendall, 10 October 1922, Pammel Papers.

24. Pammel to Gov. N. E. Kendall, 5 July 1923; Pammel to Mrs. E. F. (Mary) Armstrong, 17 November 1925; Mary C. Armstrong to Pammel, 20 November 1925; Pammel to Mr. E. F. Armstrong, 21 November 1925; Pammel to Mrs. E. F. (Mary) Armstrong, 21 November 1925; E. F. Armstrong to Pammel, 25 November 1925; Pammel to Mrs. E. F. (Mary) Armstrong, 30 November 1925; Mary C. Armstrong to Pammel, 27 November 1925; May McNider to Pammel, 20 October 1926, Pammel Papers. Others who served on the board during the 1920s included Euclid Saunders, a banker from Emmetsburg and former president of the Iowa Conservation Association; Clifford Niles of Anamosa; State Senator Willis G. Haskell, a well-known businessman from Cedar Rapids who served as a member of the standing committees on appropriations, highways, mines and mining, public utilities, and railroads; George Wyth of Cedar Falls, president of Viking Pump Company and the driving force behind Cedar Falls's city park system; and former State Senator Byron Newberry of Strawberry Point, who lent initial support to the state parks bill in 1917 and was instrumental in establishing the first state park, Backbone State Park in Delaware County. 
AS LONG AS PAMMEL WAS AT THE HELM, the Board of Conservation defined "conservation" broadly. According to its chairman,

The persons who framed the law had in mind the preservation of animals, rare plants, unique trees, some unique geological formations, the preservation of the Indian mounds, rare old buildings where Iowa history was made.... The framers of this law wished to show generations yet unborn what Iowa had in the way of prairie, valley, lake and river. It was felt that a part of this heritage left to us was not only for the present generation, but that its citizens of the future had a just claim on this heritage.

Noticeably missing from this mission statement, of course, was soil conservation. This is not to say that conservationists were unconcerned with soil erosion, only that they had little influence with farmers. In order to address concerns that could be channeled into park settings, the board envisioned creating a three-tiered system: state parks of "peculiar scientific, historic and recreational value"; highway parks where tourists could picnic without trespassing; and lake parks "to provide healthy recreation in the water and on its shore." 25

The first order of business for the new Board of Conservation was to begin acquiring land, which the board did without delay. Building on the list of suitable park areas that Shimek had presented in 1917, the board conducted a statewide survey to identify sites desirable for acquisition. A formal report published in 1919 contained a target list of ninety-eight scenic, sci-

25. L. H. Pammel, "The Arbor Day, Park and Conservation Movements in Iowa," part 2, Annals of Iowa 17 (1930), 293; L. H. Pammel, prepared remarks for introducing Governor Harding at Backbone State Park dedication, 28 May 1920, typescript, Pammel Papers. Pammel, at least, seems to have had some difficulty seeing any way to integrate agricultural concerns into the conservation movement. In 1921 Governor Kendall solicited Pammel's comments on two proposals for governmental reorganization: the first, to consolidate animal husbandry, weather and crop services, animal health, and related functions into a State Department of Agriculture; and the second, to consolidate under one umbrella the State Horticultural Society, the State Library, the Bureau of Public Archives, the Iowa Academy of Science, and the State Board of Conservation. Pammel opposed the second proposal, pointing out that the Board of Conservation simply could not be consolidated "with the other lines of work." He did suggest, though, that the Fish and Game 
entific, and historic areas, thereby laying the foundation for much of the board's work over the next decade. By the end of 1922, fourteen state parks had been established. In 1930 the number reached forty. Rice Lake State Park was the first of several meandered lakes to be declared state parks as a result of a 1921 change in the law that gave the board jurisdiction over the seventy meandered lakes and streams identified by the Highway Commission's study. ${ }^{26}$

The 1919 state park survey, in particular, focused nationwide attention on Iowa, prompting the U.S. Department of the Interior to select Iowa as the location for a national conference on state parks. E. R. Harlan and O. Van Wyck, Jr., worked with Secretary of the Interior John Barton Payne and National Park Service Director Stephen T. Mather to organize the conference, which convened on January 9, 1921, at Des Moines. Approximately two hundred delegates from twenty-four states and the District of Columbia attended the three-day event to discuss issues of common concern in the growing state park movement. Out of the Des Moines meeting came a formal organization, named after the convening body, the National Conference on State Parks. ${ }^{27}$

During the 1920s the board sought to maintain its ties to conservationists at large by publishing a quarterly under the title Iowa State Parks Bulletin, which contained information about board activities; reports on conferences, state park

Department and the Iowa Geological Survey be subsumed under the Board of Conservation. What he did not suggest is equally interesting. Having studied newly formed departments of agriculture in several other states, Pammel had many ideas for lowa. None of them involved coordinating the conservation of natural resources with state-supported agricultural research activities or state regulatory powers over agriculture. At most, he thought the state should "work out a constructive program [of] bringing all the divergent interests together." See Pammel to Gov. N. E. Kendall, 27 January, 1 February 1921, and 2 October 1922, Pammel Papers.

26. State Board of Conservation, Iowa Parks: Conservation of Iowa Historic, Scenic, and Scientific Areas (Des Moines, 1919); Christensen, "The State Parks of Iowa," 382-86.

27. George Bennett, "The National Park Conference at Des Moines, Iowa, January 10-11-12, 1921," Iowa Conservation 5 (1921), 14-25; and Iowa State Parks Bulletin 1 (July 1923), 5. 
dedications, and other events; and articles on a variety of conservation-related topics. As editor of the Bulletin, Pammel consistently emphasized the importance of conservation over recreation. In a 1925 piece, for instance, he noted that the recreational dimension of state parks was important, but cautioned, "Our modern life has brought so many changed conditions that conservation must be urged much more strongly than it has been in the past." 28

In the early years of its existence, the Board of Conservation drew support from its parent organization, then in its third incarnation as the Iowa Conservation Association. For instance, in 1920 the ICA recommended to the board a "policy of natural parks as opposed to landscaped parks," noting that "the primary purpose of State Parks is the preservation of certain areas in unmodified condition." This recommendation coincided with informal discussions then taking place concerning the need for a consulting landscape architect. After receiving a number of unsolicited inquiries from professional firms offering their services, the board quietly let it be known that it would not squander funds on expensive professional fees and that it would consider only landscape architects who were sympathetic to its goals. Writing to A. T. Erwin, a colleague in the landscape architecture department at Iowa State, Pammel confided that the Board of Conservation did not want the "ordinary kind of landscaping," but wanted all state parks to "remain as nature left them with simple driveways through the premises."29

28. [L. H. Pammel], “Conservation," Iowa State Parks Bulletin 3 (NovemberDecember 1925), 66. Pammel and Harlan were instrumental in launching the Bulletin, although it proved to have a relatively short life, chiefly because the board chose not to spend any money appropriated for state park acquisition and development on that endeavor. Publication therefore depended on outside funding or other pots of money within state government. Funds proved difficult to secure on an ongoing basis, and the quarterly ceased publication after only four volumes, 1923-1927. The board did, however, set a precedent. In 1942 its successor agency, the State Conservation Commission, began publishing a similar newsletter, Iowa Conservationist, which continues to the present. It should not be confused with Iowa Conservation, a quarterly published by the Iowa Conservation Association, 1917-1923.

29. G. B. MacDonald to Pammel, 7 May 1920; Pammel to A. T. Erwin, 25 August 1919, Pammel Papers. 
At the urging of May McNider, the board first engaged the firm of Pearse-Robinson, with offices in Des Moines, Chicago, and St. Louis, to provide landscape architectural services. ${ }^{30}$ This was not an unsatisfactory arrangement from a professional standpoint, but the board, conscious of budgetary priorities, felt it would be more advantageous to have the landscape architecture and forestry departments at Iowa State College provide those services. College administrators and department heads were sympathetic to the needs and desires of the board, but they were not terribly enthusiastic about taking on added responsibilities without some formal directive. That came in 1923 when the Forty-first General Assembly passed a bill authorizing the Board of Conservation to call upon Iowa State College for landscape architectural services, which were to be rendered gratuitously with the board paying expenses only. ${ }^{31}$ Shortly thereafter, the landscape architecture department assigned faculty members to work with the board on a rotating basis. At that point, the board finally adopted a policy on "landscape work in state parks." Its policy statement definitely reflected the ICA's recommendations of four years earlier urging resource conservation rather than aesthetic values. Landscape plans, as well as land acquisitions, were to be based on topographical surveys. Landscape architects were to plot overgrazed, eroded, or otherwise denuded spots "and then with the assistance of [a] botanist (ecologist) ... replant these areas with plants suitable for such areas." Suitable plants meant "native plants." In parks where there was evidence of native "boreal or northern plants," those were to be restored. In parks

30. Francis A. Robinson to Mrs. C. H. McNider, 16 May 1923; Robinson to Pammel, 5 June 1923; McNider to Pammel, 6 June 1923; copy of "Agreement for the Services of [Pearse-Robinson] Landscape Architects on the Property of Board of Conservation," Pammel Papers.

31. Pammel to P. H. Elwood, Jr., Landscape Architecture Dept., 4 October 1923; Elwood to Pammel, 5 October 1924; Pammel to C. L. Niles, 1 December 1923; W. E. G. Saunders to Pammel, 13 June 1924; R. E. Johnson, secretary of the Executive Council, to members of the Board of Conservation, memorandum dated 24 June 1924; Saunders to Pammel, 28 June 1924; Pammel to Saunders, 2 July 1924; R. K. Bliss, director, State Extension Service, to Pammel, 13 October 1924; Pammel to Bliss, 7 October 1924, Pammel Papers. 
where there were "prairies" and "dry ridges with sparse growth," those plant communities were to be maintained. ${ }^{32}$

THE FRAMERS of the state parks act may have envisioned a park system that first and foremost protected areas of scientific value, historical interest, and natural beauty, but they also recognized the importance of recreational use. What most of them had in mind, though, was public access to these special areas for quiet pursuits, such as hiking, picnicking, leisurely auto tours, fishing, and meditating at scenic overlooks. This concept of leisurely recreation meshed nicely with another concern that any number of contemporary writers nebulously described as "human conservation" or "conservation of life." Women, in particular, urged a connection between natural resource conservation and human resource conservation. Rose Schuster Taylor, another woman active in both the IFWC and the Iowa Conservation Association, wrote in 1917, "The waste of our fields, our soils, our forests, our birds, our flowers, has led us to emphasize conservation. The waste of human life needs also the cry of conservation for its protection and preservation. ${ }^{\prime 33}$ In practical terms, the concern for human conservation translated into promoting the recreational value of parks. Nonetheless, in the early years, the board gave a cool reception to proposals for overnight camping facilities, park concessions, and similar amenities.

The board's vision was not shared universally, of course. Minor conflicts rippled through board activities from the very beginning, and by 1922 the first major controversy emerged over the issue of dams in state parks. During much of 1922 and 1923 the fate of Ledges State Park hung in the balance after Iowa Traction Company (later Iowa Light and Power) of Cedar Rapids proposed to erect a series of hydroelectric dams on the Des Moines River, one of which was to be located in Boone County near the park. In May 1922 the company requested permission from the Board of Conservation to overflow about

32. Policy statement adopted at the 21 July 1924 meeting of the Board of Conservation, as recorded by Pammel in a memo to the file, Pammel Papers.

33. Mrs. H. J. Taylor, "Conservation of Life Through City Parks," Iowa Conservation 1 (1917), 13. 
150 acres of the park. ${ }^{34}$ That touched off a round of delicate discussions among the members of the board while they searched to establish their legal rights and assess the politics of the situation.

The 1921 legislation amending the Holdoegel Act gave the board jurisdiction over all meandered streams and lakes. That made the board an "interested party" at the very least, but it was not clear what legal rights the law endowed. Consequently, the board took its time studying the issue, requiring Iowa Traction to supply detailed maps and to flag the line of inundation. Between July 1922 and February 1923, employing ad hoc procedures similar to the present-day environmental review process, several members visited the site, probed local sentiments, and solicited outside opinion from landscape architects and engineers. The board also requested that the attorney general render an opinion regarding its legal right to represent the state in matters pertaining to the protection, maintenance, improvement, or development of the Des Moines River within the park. ${ }^{35}$

Throughout the proceedings, individual members avoided taking a public stand on the issue, in part because they realized the final decision could tie the board's hands with respect to other actions. That is where the issue got sticky, since no one was opposed to building dams to create swimming and fishing areas. As a case in point, at the same time the board was skirmishing with Iowa Light and Power over the proposed hydroelectric dam in Ledges, it was considering the construction of a low dam across Prairie Creek in Dolliver State Park to create a thirty-acre swimming "lake." 36 Likewise, in Backbone State

34. "Before the State Board of Conservation: In the Matter of the Overflowing of Certain Lands in the State Park Near the City of Boone, Iowa, by Reason of the Proposed Hydro-Electric Project of the Iowa Traction Company," undated typescript, filed with Edgar R. Harlan, secretary of the board, on 17 May 1922, Pammel Papers.

35. Minutes, Board of Conservation meeting held at Boone, Iowa, 14 July 1922; E. R. Harlan to Pammel, 3 October 1922; Pammel to Harlan, 5 October 1922; Harlan to Pammel, 20 December 1922; Pammel to Harlan, 23 December 1922; Pammel to Harlan, 1 February 1923; Pammel to Harlan, 14 February 1923; W. G. Haskell to Attorney General Ben J. Gibson, 2 September 1922, Pammel Papers.

36. This matter never got beyond discussion, however. The idea was aban- 
Park, where the Maquoketa River had been dammed in the nineteenth century to power a mill, the board left the existing structure intact, eventually replacing it and improving the lake with swimming and boating facilities.

Local sentiment ran hot and cold for Ledges, another complicating factor. In 1919-1920 citizens had contributed a total of sixteen thousand dollars toward land acquisition to protect from despoliation the limestone ledges that gave the park its name. Two years later, many of the same people enthusiastically supported a dam that would inundate the very heart of the park, flooding 75 percent of the existing recreational land as well as a scenic view of the ledges. The editor of the Boone News-Republican proclaimed that "if it comes to a show down between the park and the dam, 'We're all for the dam first.'" The park had its local protectors, to be sure, who urged the board to stand firm against encroachment. Nevertheless, more than a few people found the idea of a large lake with opportunities for resort and amusement development much more enticing than a six-hundred-acre scenic woodland river valley with a few camping areas, picnic spots, and hiking trails. "What is the sacrifice of a tree or two to the wonderful opportunity for cheap power for factories and the added pleasure of a water resort," the Boone News-Republican asked rhetorically. ${ }^{37}$

All this left members of the Board of Conservation scratching their heads. In the face of growing local support for the dam, compromise positions inevitably cropped up. Landscape architect Francis A. Robinson prepared an equivocal report in which he admitted that raising the water to the level proposed would result in "an irreparable loss" of park value, but pointed out the added benefit of "a body of water large enough to

doned after consulting landscape architect R. J. Pearse pointed out that such a structure would require expensive flood gates and, even with such protection, would expose large areas of the park to flooding. L. H. Pammel to Mrs. C. H. McNider, 24 November 1922; E. I. Leighton, president, Fort Dodge Chamber of Commerce, to Pammel, 13 February 1923; Pammel to Leighton, 14 February 1923; "Report on the Existing Conditions and Proposed Landscape Development on the Tract of Land Near LeHigh, Iowa, Known as Dolliver Park," submitted by R. J. Pearse, A.S.L.A., to the Board of Conservation, 19 June 1923, Pammel Papers.

37. Boone News-Republican, 13 February 1923. 
afford recreation for a large group of people in the torrid climate of our summer." In his report and in a personal appearance at a conference held on February 9, 1923, Robinson suggested that if the power company would agree to maintain the water at a lower, fixed level, the loss of existing recreational and scenic lands might not be too great and the park would have the added value of a lake. ${ }^{38}$

Robinson's suggested compromise was politically attractive, and several local citizens urged the board to adopt it. However, it was equally unacceptable to the power company and to members of the board. On the one hand, the power company could not commit to any fixed water level and also generate electric power without interruption. On the other hand, as Pammel put it, "Parks are created for scientific, recreational and historic values. The point is, is the company going to destroy these three values?" Board member May McNider framed the answer clearly. "The character of the Ledges Park would be destroyed by this dam. It is our duty to protect the natural features of this state, and preserve it for our children. The lower Ledges would be flooded and could not be used. I think that if the dam ever goes in there as planned you might as well say good-bye to the park." ${ }^{\prime 39}$ In the end, no dam on the Des Moines River backed water into the park. Ledges emerged from the skirmish untouched.

Unfortunately, the Board of Conservation resolved the controversy without establishing any clear policy on dams in state parks, and the issue came back to haunt it a few years later. In 1927 Central States Electric Company proposed placing a dam twenty-six feet high across the Des Moines River near Dolliver State Park, some distance north of Ledges State Park in Webster County. Although this proposal also had plenty of local support, many people who had donated money

38. "A Report on the Effect of the Proposed Location of a Power Dam in the Des Moines River on the Park Values of the Ledges," presented to the Board of Conservation, 21 February 1923; "Abstract of Conference between Board of Conservation \& Parties Interested in the erection of a dam by the Iowa Light \& Power Company to affect the Ledges State Park," [9 February 1923], typescript, pp. 7-8, Pammel Papers.

39. "Abstract of Conference between Board of Conservation \& Parties Interested in the erection of a dam," 19-20. 
to create the park in the first place stepped forward to help mobilize opposition, just as had happened in Boone County. Controversy fixed on Woodman Hollow, a designated preserve containing several rare plant species, which would have been completely flooded. C. V. Findlay, the mayor of Fort Dodge, was one of several citizens who wrote unsolicited letters protesting the dam.

From actual experience ... I know that the electric light utility companies all over lowa are throwing a net work of high lines, power plants, and hydro-electric dams that will be a serious menace to the rights of the people of Iowa some day. Before we wake up to the fact, we will be tied hand and foot. ... Personally, I should dislike to see any corporation given privileges of the river that will in after years be detrimental to the development of the state park and hinder the preservation of the places of beauty along the river.

In October 1927 the Board of Conservation went on record in opposition to the dam, stating that it would threaten "all the features which make this park valuable and worth conserving" and that "to agree to the construction of a dam in Dolliver would be breaking faith with the people of Webster County who contributed $\$ 11,000 "$ to acquire park lands. ${ }^{40}$

Louis Pammel, who had just retired from the board, continued his activism as a private citizen, working to defeat what were always vaguely described as "selfish interests" promoting the dam. He praised the board's resolution, sent a letter of protest to Governor John Hammill (who had publicly stated that the people of Webster County could have whatever they wanted), wrote letters to other high officials in state government, submitted an "interview statement" to the Des Moines Register, and, once the governor agreed to a special hearing before the State Board of Conservation, rounded up as many fellow scientists as he could to appear and testify against the project. ${ }^{41}$ The hearing, held December 7, 1927, in Des Moines,

40. C. V. Findlay to Mrs. E. F. [Mary C.] Armstrong, 30 September 1927; Open letter from Mary C. Armstrong to the citizens of Webster County, 18 October 1927, Pammel Papers.

41. The Pammel Papers contain numerous letters and documents pertaining 
reportedly was well attended. After a day of listening to both supporters and opponents, the Board of Conservation and the Executive Council agreed to defer making a decision on the granting of a franchise. ${ }^{42}$ The deferred decision turned out to be permanent; no dam went up across the Des Moines River in or anywhere near the park. Although the Board of Conservation again failed to adopt a formal policy statement concerning the placement of dams in state parks, the situations at Ledges State Park and Dolliver State Park appear to have set the rule: hydroelectric dams were considered an incompatible use of state parks and preserves.

HYDROELECTRIC DAMS represented the most serious outside threat to the system, but ultimately it was the tremendous success of state parks that transformed conservation goals in ways the original framers did not foresee. The enthusiasm for state parks during the 1920 s has been attributed to a number of circumstances - chief among them the advent of the automobile. During the 1910s, the automobile became a "common luxury," which created a demand for good roads as well as convenient wayside and recreational parks. By the late 1920s, forty-five states had some form of park or recreation system. ${ }^{43}$ The combination of private automobiles and public parks improved with roads, shelter houses, and camping facilities

to the proposed dam. Cited here are Pammel to Gov. John Hammill, 24 October 1927; Pammel to the other members of the Executive Council, open letter dated 25 October 1927; "A Proposed Dam in the Dolliver Memorial Park, Fort Dodge," interview statement written by Pammel and noted in pencil as having been sent to the Des Moines Register, 25 October 1927; Pammel to members of the Board of Conservation, 25 October 1927; Pammel to Prof. L. D. Weld (Coe College, Iowa Academy of Science), 9 and 15 November 1927 as well as return correspondence; Pammel to Mrs. F. E. Whitley (Iowa Federation of Women's Clubs), 28 November 1927; Pammel to Dr. A. L. Bakke, Dr. I. E. Melhus, Dr. J. E. Guthrie, Dr. C. J. Drake, and Dr. E. F. Smith (Iowa State College), open letter of 28 November 1927; Pammel to Dr. James H. Lees (Iowa Geological Survey), 2 December 1927 and return correspondence; Pammel to Dr. H. S. Conard (Grinnell College), 3 December 1927 and return correspondence; Pammel to Dr. B. Shimek (University of Iowa), 3 December 1927 and return correspondence.

42. Des Moines Register, 16 December 1927.

43. Christensen, "The State Parks of Iowa," 351-52; Beatrice Ward Nelson, State Recreation (Washington, DC, 1928), 5. 
gave rise to that venerable American institution known as the family summer vacation. One certainly cannot deny that inexpensive and easily available outdoor recreation became the chief attraction of state parks during the 1920s, but it does not account for the fact that the initial call for rural parks actually predated the "automobile age." Part of their appeal may have been that parks held psychic value, the "human conservation" that many park advocates sought. In this vein, James Speed, editor of Southern Agriculturist, touched upon a deeper felt need for parks. "When a region is developed for the preservation of wild life we at once speak of it as a reservation or a sanctuary for animals and birds ... when in reality sanctuaries do not tame the animals; but they do tame men and women." 44 Whatever attracted people to Iowa's state parks, visitor statistics bear witness to their instant popularity. During the 1923 season, an estimated 232,000 people visited the seventeen state parks that had been established by then, representing practically every county, more than thirty states, and several foreign countries. Both the number of parks and the number of visitors climbed steadily throughout the decade. During the 1930 season, approximately 1,750,000 visitors passed through Iowa's forty state parks. ${ }^{45}$

Increasing public use put pressure on the Board of Conservation to provide visitor facilities. By 1930, seven lodges had been erected in six parks, and camping areas were available at ten parks. During the 1930s, the extensive park improvement program carried out under the auspices of various New Deal agencies vastly enhanced park facilities. Correspondingly, the number of visitors continued to rise. In 1941 when the State Conservation Commission reclassified its properties, Iowa had sixty-one parks, preserves, and recreation reserves, well above the national average of twenty-nine park properties per state;

44. James Speed, "The Farmer Needs Parks," address delivered at the Ohio Valley Regional Conference for State Parks in 1925, reprinted in Herbert Evison, A State Park Anthology (Washington, DC, 1930), 46.

45. "Attendance at State Parks During the Season of 1923," Iowa State Parks Bulletin 1 (1923), 11-12; Iowa Board of Conservation, Administration of Iowa Parks, Lakes and Streams by the Board of Conservation (Des Moines, 1931), 8-9. 
including state forests and wayside parks brought the total to seventy-three. ${ }^{46}$

Depression-era civil works and conservation programs devised to jumpstart the economy changed the look of national and state parks throughout the country. The rustic architectural style associated with these programs has been the subject of several studies. ${ }^{47}$ In Iowa, as elsewhere, the Civilian Conservation Corps (CCC) contributed more to the development of state parks than any other governmental agency or program. Nearly forty-six thousand enrollees carried out projects in Iowa, and more than six hundred CCC-built structures still stand in Iowa's state parks. The contributions of other agencies should not be overlooked, though. Four other New Deal agencies participated in park development during the 1930s and early 1940s: the Works Progress Administration, the Public Works Administration, the Civil Works Administration, and the National Youth Administration. Next to the CCC, the WPA was most involved in parks projects, contributing to the development of twenty-seven state parks in Iowa. ${ }^{48}$

The infusion of federal money completed the transformation of conservation goals with respect to parks. That transformation, however, was greatly aided by The Iowa Twenty-Five Year Conservation Plan, which placed Iowa in a good position to take advantage of the federal government's largess. When President Franklin Roosevelt authorized the CCC in March

46. Board of Conservation, Administration of Iowa Parks, 29; Minutes, Board of Conservation, 13-14 February 1941, Iowa Department of Natural Resources. 47. See, for instance, William C. Tweed, Laura E. Soulliere, and Henry G. Law, National Park Service Rustic Architecture: 1916-1942 (San Francisco, 1977); Joyce McKay, "Civilian Conservation Corps Properties in Iowa State Parks: 1933-1942," NRHP Multiple Property Documentation Form and Nominations, August 1989; Mary Elizabeth McCahon and John Herzan, "Connecticut State Park and Forest Depression-Era Federal Work Relief Programs' Structures," NRHP Thematic Resources Nomination, December 1985; James M. Denny and Bonita Marie Wright, "Emergency Conservation Work (ECW) Architecture in Missouri State Parks, 1933-1942," NRHP Thematic Resources Nomination, December 1984; Rolf T. Anderson, "Minnesota State Park CCC/WPA/Rustic Style Historic Resources," NRHP Multiple Property Documentation Form, 1988; Glory-June Greiff, "New Deal Resources in Indiana State Parks," NRHP Multiple Property Documentation Form, July 1991.

48. Rebecca Conard, "The Conservation Movement in Iowa, 1857-1942," NRHP Multiple Property Documentation Form, July 1991, Section E, 78-85. 
1933, the State Board of Conservation and the Fish and Game Commission had just completed the twenty-five-year plan. Since federal regulations required applicant states to submit a planning document in order to receive funds, Iowa got to the trough early. ${ }^{49}$

The twenty-five-year plan addressed many areas of concern besides state parks and preserves, including erosion control, surface waters, woodlands, fish, game, and scenic highways. It articulated specific conservation areas that had heretofore been wrapped up in the state park system. Forest conservation, for instance, was finally recognized as a distinct area with concerns that reached beyond the reforestation of certain parks and preserves. Likewise, soil conservation finally received official recognition. When the Board of Conservation and the Fish and Game Department were folded into a new State Conservation Commission in 1935, all but one of those concerns, soil conservation, were rationalized within the organizational structure. With respect to the park system, the plan envisioned a clear distinction between parks and preserves. Preserves would "save [the] most important features throughout the state for the use of the large number of people deeply interested in their unique character." In general, preserves would be smaller than parks, and large crowds would be discouraged, although picnicking, hiking, boating, and swimming might be allowed. Parks would be accessible by good roads and contain facilities for large-scale outdoor recreation, including "picnic and camping grounds; hiking trails, nature trails and perhaps riding trails; swimming and boating; zoos or museums; inns and cabins; fishing; play fields (not 'playgrounds'); tobogganing, coasting, skiing; and sometimes golf." In addition, the plan recommended that state parks be distributed evenly throughout the state and so located that no state resident had to drive more than two hours to reach one. In sum, the plan associated recreation with parks; conservation with preserves. ${ }^{50}$

The success of the twenty-five-year plan transformed the park system. Originally conceived primarily as a means of resource conservation, money and labor for park improve-

49. McKay, "CCC Properties in Iowa State Parks," Section E, 61.

50. Crane and Olcott, Report on Twenty-Five Year Conservation Plan, 8-9. 
ments tipped the balance in favor of recreation. So long as the Board of Conservation maintained a policy of spending money first for land acquisition and delaying improvements, it could postpone the inevitable decision of how much and what kinds of public use to accommodate. But a growing number of park visitors could not be ignored forever. As state parks became more popular, resource conservation yielded the driver's seat to recreation.

THE HISTORY OF BACKBONE STATE PARK illuminates the crossroads at which conservation had arrived by the early 1930s. When the newly organized State Board of Conservation got down to work in 1918, an area known as the Devil's Backbone, south of the town of Strawberry Point in Delaware County, went to the top of the potential park list. The area had long been a favorite of natural scientists because its ancient geologic formations had escaped scouring by ice age glaciers. As the idea of rural parks took hold in the late nineteenth century, these same people began to look at Devil's Backbone as more than a favorite haunt. They now saw an unspoiled natural wonder worthy of special protection. Samuel Calvin, a pioneer Iowa botanist, spoke for many of his colleagues when he wrote in 1896, "The beauty, the seclusion, the attractiveness of the place, are certain to be appreciated more and more as the years go by, provided short-sighted, unaesthetic avarice does not transform its forest lands into pastures, or does not attempt to 'improve' it for the sake of converting it into a profitable summer resort." ${ }^{\text {51 }}$

Before the board organized, a local group initiated the process of securing the Backbone region as a state park. Then, when the board convened in December 1918, it followed through by voting to acquire at least twelve hundred acres in the area. Backbone State Park was formally dedicated on May 28,1920 , but in keeping with board policy, comparatively little development took place until 1933. In 1922 the board arranged through State Forester G. B. MacDonald to have a stand of white pines planted in the park. The Iowa Daughters of the

51. Samuel Calvin, "The Devil's Backbone," Midland Monthly 6 (July 1896), 26. 
American Revolution donated stock for an additional stand of six thousand trees planted in $1928 .^{52}$

Parkland acquisition brought with it some existing conditions and a few locally promoted ideas that gave the board ample opportunity to contemplate just what image of state parks it hoped to establish. Concession stands in the park became an issue early in 1922, when A. D. Ownby of Winthrop requested permission to establish a small grocery store in the park. E. R. Harlan and Louis Pammel decided this would be a good time to establish a policy on park concessions, noting that Ownby's request was one of several such proposals to have come forth. Pammel personally opposed concessions of any type in state parks, but others on the board were of a different mind, and the question was referred for further study. As it turned out, Ownby was allowed to build his store in the park without benefit of any established policy; but when he asked for a rebate on his concession fee later in the year "because floods and untoward circumstances ha[d] prevented a profitable business," the board voted to terminate his contract. Ownby somehow managed to get his concession renewed, which served to keep the issue alive. Pammel asserted in a report to the board on August 14, 1923, that the citizens of Strawberry Point did not want a concession granted at the upper end of the park, but one suspects his "report" was merely a vehicle for advancing his own point of view. Nevertheless, early in 1924 the board attempted to purchase Ownby's store, presumably in an attempt to close the matter amicably. After he refused an offer of $\$ 335$, the board ordered him to move the building because its location "interfered with the beauty of the park." Later, the board voted not to let any concession contract for 1925. That was the end of the park store until $1933 .{ }^{53}$

52. Pammel's park dedication speech, undated typescript, Pammel Papers; Minutes, Board of Conservation, 27 December 1918, in Iowa Parks: Conservation of Iowa's Historic, Scenic and Scientific Areas (Des Moines, 1919), 11-13; Minutes, Board of Conservation, 26 April 1922, in Annals of Iowa 13 (1923), 388; Minutes, Board of Conservation, 2 May and 5 June 1928, Iowa Department of Natural Resources, Des Moines (hereafter cited as IDNR).

53. E. R. Harlan to A. D. Ownby, 16 February 1922; Harlan to Pammel, 16 February 1922; Pammel to Harlan, 18 February 1922, Pammel Papers; Minutes, Board of Conservation, 9 May 1922, in Annals of Iowa 13 (1923), 389, 
Private summer cottages provoked another dialogue. In mid-1923 landscape architect E. A. Piester called the board's attention to several "shacks" that had been built in close proximity to a well in a picnic and camping area near the west entrance. In his opinion, it was "absolutely unsatisfactory to all parties concerned to have a picnic in common with a summer home colony." Eventually the summer cottages disappeared from the park, but two stone buildings - a barn and a pumphouse-both built without board authorization, were later adapted for park use. That was not the end of the matter, though. In 1926 two citizens from Lamont formally requested permission to build private cottages in the park. The board refused and at the same time adopted a policy of not permitting private cottages in any state parks. ${ }^{54}$

As with most of the parks, a good road was the first improvement to win universal agreement. The narrow valley cut by the winding Maquoketa River presented special obstacles to road construction in Backbone. When the land was acquired, a wooden road ran through a timbered section on high ground but provided no river crossing. Since any road connecting all the proposed park entrances had to cross the river more than once, engineers had to plan for periodic flooding. In 1923 the board began working with Delaware County engineers, the State Highway Commission, and landscape architect E. A. Piester to design and build a park road system, which was completed in December $1924 .{ }^{55}$ The final plan accommodated nature to a large degree by utilizing concrete fords rather than bridging the river at every crossing. This meant that the park road was impassable during heavy rains,

549; L. H. Pammel, "Report on the Backbone State Park," undated typescript, referenced in the Minutes of the Board of Conservation, 14 August 1923, Pammel Papers; Minutes, Board of Conservation, 14 February, 11 April, 24 August, and 14 November 1924, IDNR.

54. E. A. Piester, "Report on Proposed Traffic System within Back Bone State Park," typescript report to the Board of Conservation, 22 June 1923, Pammel Papers; Pammel, "Report on the Backbone State Park"; Minutes, Board of Conservation, 11 June 1926, IDNR.

55. E. A. Piester, "Report on Proposed Traffic System"; Byron W. Newberry to Pammel, 17 December 1924, Pammel Papers; Minutes, Board of Conservation, 14 August 1923 through 10 October 1924, passim, IDNR. 
but its construction was considerably less expensive and there were fewer impediments to water flow.

Completion of the road opened the way for additional development. A trout hatchery had been under discussion since 1920, when the board, acting at the request of the Fish and Game Commission, first requested the assistance of faculty members at Iowa State College to site and design such a facility. Landscape architect Harold E. Pammel, Louis Pammel's son but not affiliated with Iowa State College, made several observations about the proposed hatchery in a report in September 1923. By that time, preliminary building plans apparently existed and a site had been selected. Harold Pammel considered the fish hatchery "feasible provided the structure is so constructed so as to harmonize with its surroundings." He found C. E. Cope's proposed architectural style, however, to be out of character. In 1925 the board finally gave the Fish and Game Department permission to erect a trout hatchery on a parcel of about five acres near Richmond Springs and to draw water from the springs for the rearing ponds. Three years later the board gave Fish and Game permission to use an additional fifteen acres. C. E. Cope's design was abandoned in favor of a more appropriate rustic architectural style and an informal site plan. The trout hatchery complex contained the hatchery building itself, a garage, two service buildings, and a dozen ponds and raceways situated on a sheltered grassy meadow not far from the Maquoketa River. A residence for the custodian sat on a knoll overlooking the complex, and a long, curving stone wall with flood gates protected the rearing ponds from occasional flood waters. Rusticated limestone replaced the brick and filligree envisioned by Cope. ${ }^{56}$

The year 1925 marked the real beginning of development within the park, although the extent of improvements between then and 1933 was modest compared to the development that followed. In addition to authorizing construction of the trout

56. Minutes, Board of Conservation, 23 April 1920, in Annals of Iowa 13 (1921), 58; Minutes, Board of Conservation, 14 September 1923 and 4 August 1928, IDNR; "Report of H. E. Pammel, Landscape Engineer, on Location of Permanent Features in Backbone State Park," 21 September 1923, Pammel Papers; Map of the existing fish hatchery site plan prepared for Job No. 713, "Obliteration," by CCC Camp SP-17, c. 1933, IDNR. 
hatchery, the board allocated one thousand dollars to rebuild the "unauthorized" stone barn for use as a custodian's lodge, with the work to be done by Anamosa prison inmates. The board also approved plans to construct a new barn adjacent to the converted structure in 1925. Landscape architect John Fitzsimmons drew up designs for both buildings, handsome structures with lower walls of stone construction that fit the rustic architectural style then coming into vogue for park buildings. Other improvements authorized in 1925 were stone entrance pillars and a shelterhouse, also to be built by Anamosa inmates. If the shelterhouse ever was constructed, it is no longer standing. The portals, for which the citizens of Strawberry Point provided the stone and sand, still stand at the north entrance. Landscape architect Francis A. Robinson designed the portals, rather simple rectangular columns with hipped caps. After some delay, the portals were finished in time for a statewide picnic held at Backbone in October 1926, at which time Governor John Hammill dedicated the trout hatchery and the road system. ${ }^{57}$

The board authorized construction of one other building prior to the extensive CCC building projects that began in 1933. That was an auditorium, still standing, located near Richmond Springs in the north end of the park, built in 1931. By that time, Pammel had been gone from the board for four years, and the vision he had sustained was beginning to fade. Conceptual drawings for the auditorium - the plans that Thomas Macbride critiqued-indicate that it was to have been part of a large nature study headquarters complex linked to Richmond Springs by foot trails and containing no fewer than three lodges, twenty-one cabins, a dining hall, and three service buildings. However, the auditorium is the only building of the proposed

57. Minutes, Board of Conservation, 13 February, 12 June, and 14 August 1925, IDNR; "Suggested Sketch for the Proposed Reconstruction of the Lodge, Backbone State Park" and "Proposed Barn Plan, Backbone State Park," prepared by the Iowa Extension Service at Ames, John R. Fitzsimmons, Landscape Architect, IDNR; L. H. Pammel, "Report on the Backbone State Park [14 August 1923]; Byron W. Newberry to Pammel, 17 December 1924; Clifford L. Niles to Pammel, 20 December 1924; Pammel to Gov. John Hammill, 15 October 1926; Hammill to Pammel, 11 October 1926, Pammel Papers. 


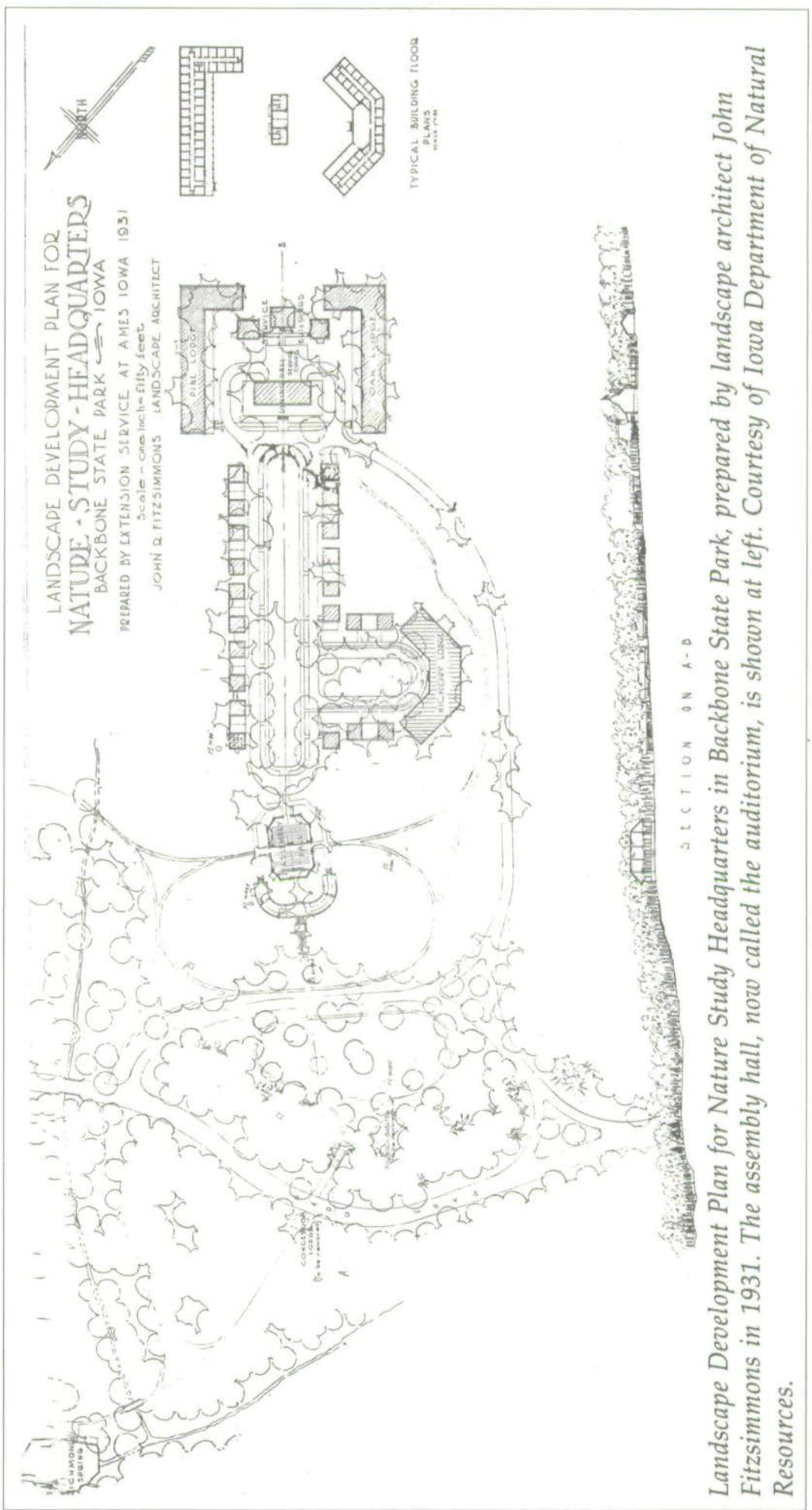




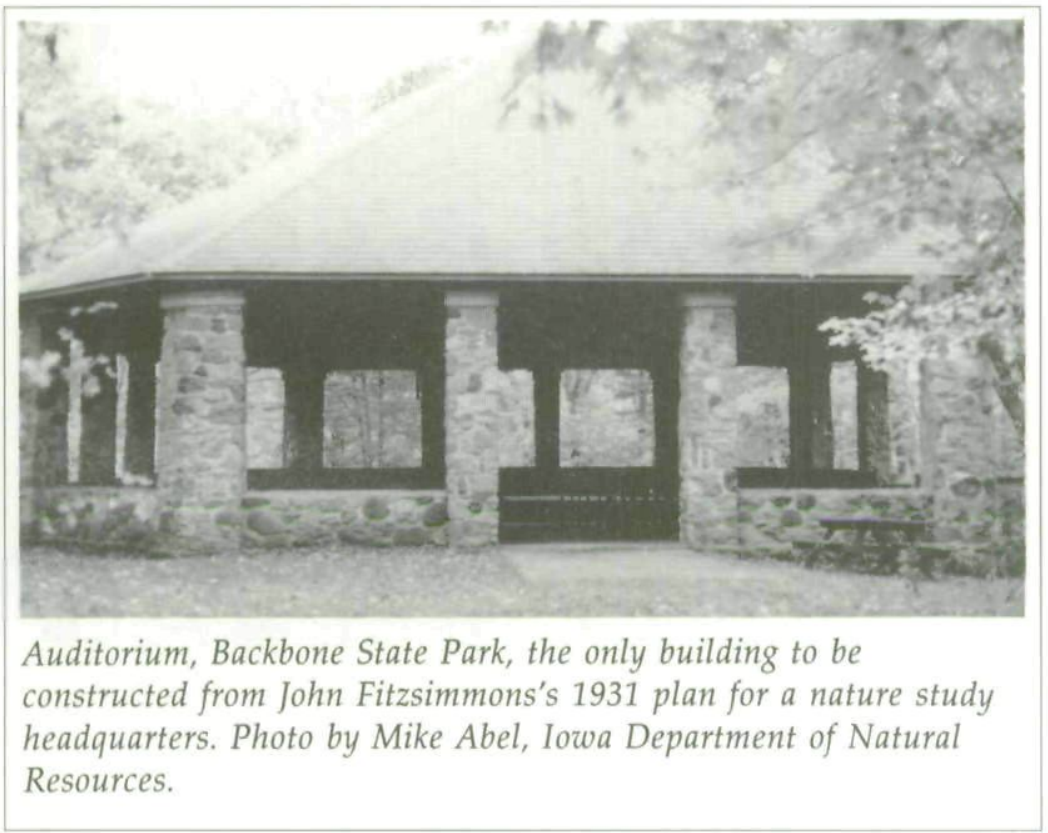

complex ever to be constructed. When the CCC program got under way in 1933, plans were downscaled to one lodge, eighteen cottages, one latrine, and an ornamental water tower. Another revision scaled the project back again, eliminating the lodge and cottages altogether and replacing existing latrines with a picnic shelter incorporating toilets and parking areas. Even the picnic shelter seems to have been abandoned later in favor of just one new latrine, which was built by CCC Camp SP $17 .{ }^{58}$

If Thomas Macbride's outspoken critique had anything to do with squelching the expansive development planned around the auditorium (and the official record is silent here), it was a small concession to what was by then considered an outmoded philosophy. Recreation scored a clear victory over resource protection as the driving force in the state park system.

58. "Backbone State Park Auditorium" and "Plan for Nature Study Headquarters, Backbone State Park," both by John R. Fitzsimmons, 1931, IDNR; CCC Work Plan and Map for Backbone State Park, 1931, IDNR; "Backbone Auditorium Area, SP17," plans prepared by the U.S. Dept. of Interior, Office of National Parks Buildings and Reservations, State Park Emergency Conservation Work, IDNR. 


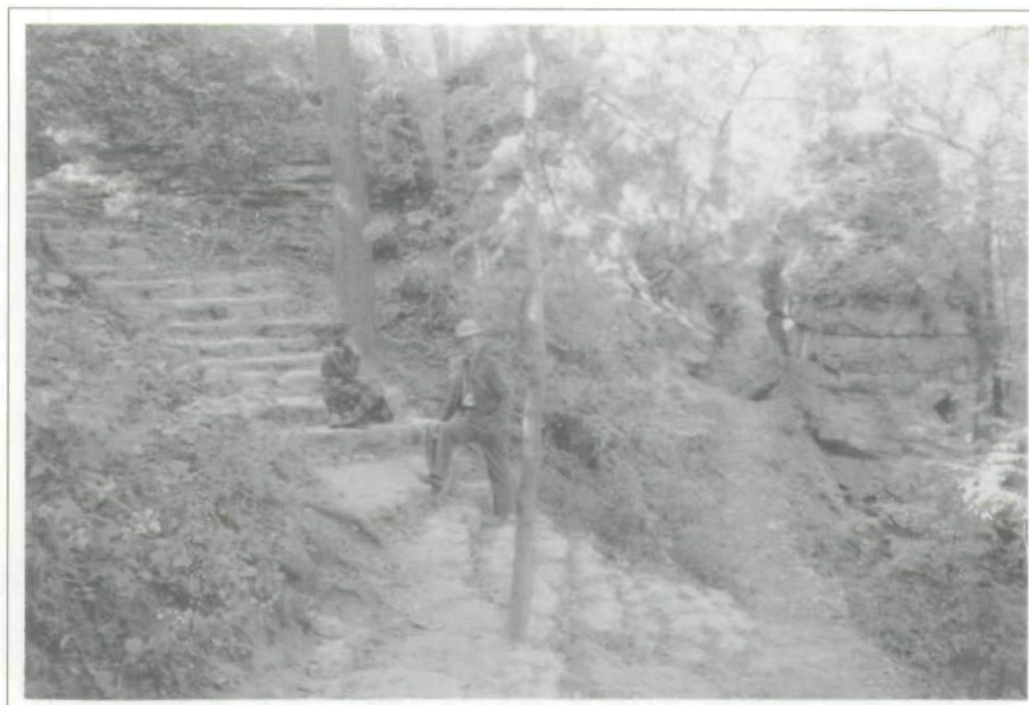

CCC crews began constructing the trail system at Backbone State Park in December 1933 and continued work for at least a year. Rough stone slabs were used to riprap hillsides in order to blend trails into the limestone outcroppings that characterize the park's natural landscape. Photo (c. 1940) courtesy of the National Archives.

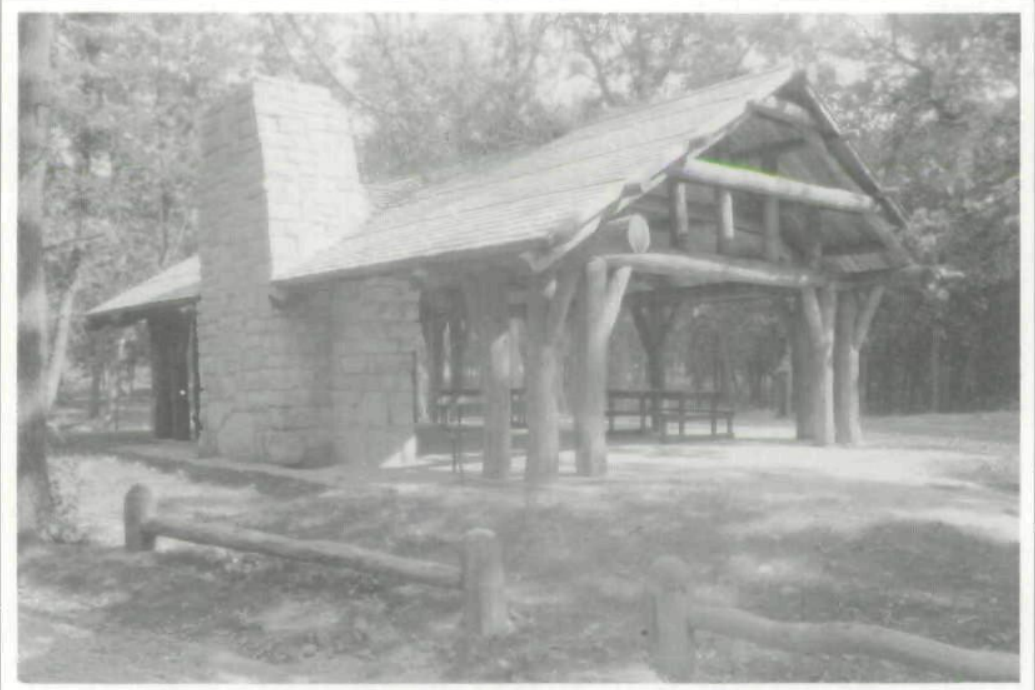

Picnic Shelter, Backbone State Park, constructed by the CCC between February and April 1935. Its location near the west entrance to the park was once the center of the park's camping area but now functions as a picnic spot. Photo (c. 1940) courtesy of the National Archives. 
Macbride did not live long enough to witness the outcome; he died in 1934 with his principled conscience further untroubled. But his exchange with Fitzsimmons is a poignant reminder that the streak of moralism that fired the first generation of conservationists had cooled. In order to protect natural resources, conservationists had to cut an epistemological pathway between preservation and public access. Macbride could give lip service to the multiple-use concept, which was the middle way, but he was steeped in the old school. In the end he had great difficulty accepting the practical results of this approach.

Between 1933 and 1942, CCC Camp SP2 (Dundee, Iowa) and Camp SP17 (in the park) developed an overnight cabin and recreational area in the southern area around the 125-acre lake. The center of the park was developed as a picnicking, hiking, and camping area. In the north end of the park, Richmond Springs itself was "enhanced" with rock work and linked to the auditorium with trail steps, although, as Macbride had wished, the area around the auditorium was left in a state of nature. The nearby trout hatchery complex, however, was expanded with several new ponds and buildings. By 1942, Backbone State Park not only was one of the largest parks in the system, but it was also one of the most extensively developed. From 1923, when the road system was built, to 1931, when the auditorium was completed, Backbone had been "improved" with perhaps as many as fifteen major structures. During the period of CCC construction, 1933 to 1942 , at least seventy additional structures were built, approximately half of which could be considered major structures, including picnic shelters, cabins, boat and bath houses, overlooks, hatchery buildings, bridges, and latrines. ${ }^{59}$

The development of Backbone State Park during the 1930s is, of course, significant for its association with the roles the National Park Service and President Franklin Roosevelt's New Deal played in disseminating rustic architecture throughout the

59. Rebecca Conard, National Register form for Backbone State Park, under "The Conservation Movement in Iowa, 1857-1942"; Joyce McKay, three associated National Register forms for Areas A, B, and C of Backbone State Park, under "Civilian Conservation Corps Properties in Iowa State Parks: 1933-1942." 


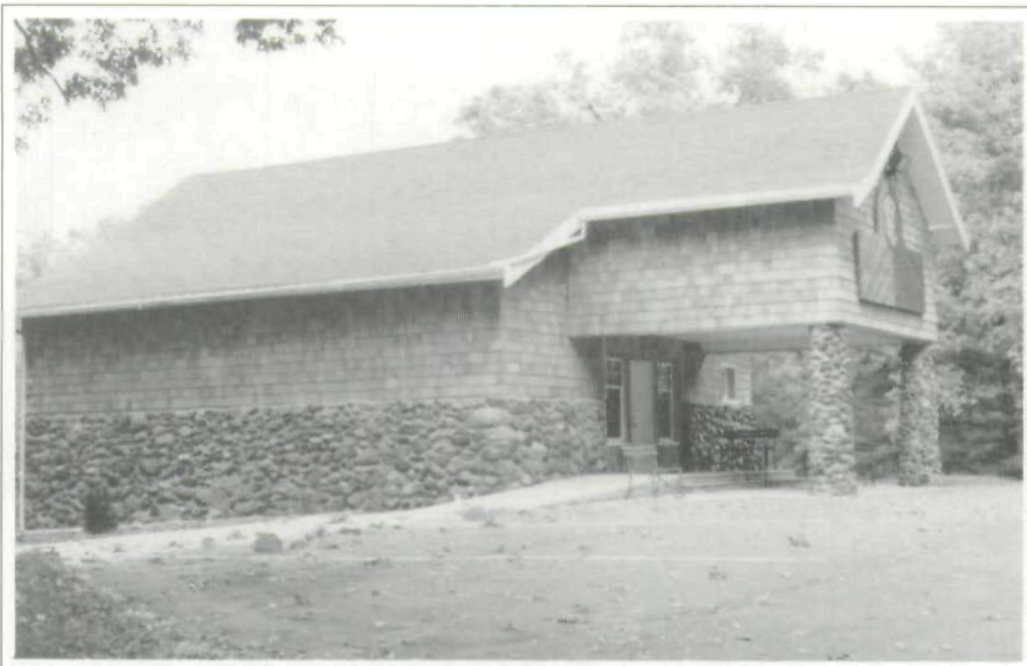

This building now serves as a CCC museum with a fine exhibit documenting 1930s park construction. Originally a barn, which according to Louis Pammel was constructed without permission from the Board of Conservation, it was remodeled in the late twenties into a residence for the park custodian. This 1990 photo by Mike Abel, IDNR, reflects the 1989 remodeling.

national and state park systems. In that sense, Backbone reflects the physical transformation of Iowa's state park system as a whole. A 1989 survey of properties built under the auspices of the Civilian Conservation Corps, the Works Progress Administration, and other New Deal agencies tallied 785 major and minor structures still standing in Iowa's state parks. ${ }^{60}$ This figure does not include structures that have been razed, so the total number of structures built would have been slightly higher. Prior to 1933, Board of Conservation policy dictated land acquisition over park improvement. As a consequence, the board did not keep systematic or complete records concerning the physical property of state parks, and construction data are thus difficult to assemble. Nonetheless, rough comparisons of pre- and post-1933 development suggest that New Deal relief and conservation programs accounted for 85 to 90 percent of

60. Joyce McKay, "Survey Report: CCC Properties in Iowa State Parks," prepared for the State Historical Society of Iowa, January 1990, 20. 
total park development completed by 1942. By any assessment, the state park system benefited from the great economic depression of the 1930s, and new structures by and large were designed to enhance the recreational potential of parks.

THE LARGER STORY, however, illuminates the tension that emerged between those who saw the state park system as a vehicle to protect splendid natural areas and those who saw the system as a vast public playground. From its inception in 1918 until the advent of New Deal conservation and relief programs, the state park system had played a central role in Iowa's conservation movement. State parks were the vehicle for arresting the slow decline of natural lakes. State parks served as a means to prevent the despoliation of unique geological formations and scenic areas. State parks provided the umbrella for preserving snatches of native flora and timber as well as important historic and prehistoric sites. State parks were a laboratory for reversing soil erosion through reforestation and restoring depleted wildlife populations through habitat protection. State parks were all of those things, but they were also public recreation areas. "Human conservation," no matter how nebulous the concept, turned out to be an important factor in transforming the system. Public access meant exposing special places-places of awesome splendor, places of pristine nature, places of quiet beauty-to the importation of "hot kitchens" and all the other accoutrements of modern outdoor recreation.

From a nationwide perspective, Iowa's state park history is additional evidence that, in politically progressive strongholds at least, the conservation movement retained its vitality through the $1920 \mathrm{~s} .{ }^{61}$ The intellectual roots of the movement run deep, springing from a fundamental belief in the efficacy of science and morality. Tempering the ethical dimension was a strain of aesthetics derived from nineteenth-century romanticism, which gave the movement a complex social texture. By

61. Donald C. Swain, Federal Conservation Policy, 1921-1933 (Berkeley, CA, 1963), demonstrated that the national conservation program did not deteriorate after passage of the Water Power Act and the Mineral Leasing Act in 1920. Rather, federal agencies expanded existing programs and formulated new policies. 
the late nineteenth century, the romantic vision of nature had given rise to a new breed of self-styled "nature lovers" urbanites who championed the aesthetic qualities of nature. The conservation movement also embodied a "spirit of efficiency" that resided chiefly in an emerging class of professionals who were trained in the sciences, or at least were schooled in scientific thought. They, along with many business leaders, were appalled at the waste of natural resources that accompanied industrialization, free-market competition, and unplanned economic development. ${ }^{62}$ Conservationists came to realize that cooperation, organization, and planning were absolutely essential in order to curb the wasteful use of natural resources. Once the federal and state governments recognized resource conservation as a legitimate function of the state, loosely organized bodies gave way to agency coordination and central planning. With that shift came government bureaucracies increasingly staffed with professional foresters, biologists, geologists, botanists, and other scientists.

All of these impulses were evident in Iowa. Two aspects, though, distinguish the conservation movement here. Chief among them was the strength of a conservation ethic. Key personalities in the movement-especially the botanists-were driven by a moral force to reclaim Iowa's natural heritage for future generations. State parks became a main focus of their efforts, but conservation education also claimed huge amounts of their time and energy. For instance, Macbride, along with Bohumil Shimek and Samuel Calvin, founded Iowa Lakeside Laboratory in 1909 as a place to "awaken" in students and the lay public alike an "interest in the natural world, and persuade them, if possible, to use it sensibly and rightly." ${ }^{\prime 3}$ Likewise, aca-

62. For good discussions of the intellectual currents of the conservation movement, see Donald Worster, Nature's Economy: A History of Ecological Ideas (1977; reprint, Cambridge, 1990); Hans Huth, Nature and the American: Three Centuries of Changing Attitudes (Berkeley, CA, 1957); Joseph M. Petulla, American Environmental History: The Exploitation and Conservation of Natural Resources (San Francisco, 1977); Lee Clark Mitchell, Witness to a Vanishing America: The Nineteenth-Century Response (Princeton, 1981); Peter J. Schmitt, Back to Nature: The Arcadian Myth in Urban America (1969; reprint, Baltimore, 1990); and Samuel P. Hayes, Conservation and the Gospel of Efficiency (Cambridge, MA, 1959).

63. Quoted in Zieglowsky, "Thomas Macbride's Dream," 49. 
demics and professionals in the conservationist movement trekked every summer to McGregor Heights in northeast Iowa, which, for two weeks, became the American School of Wild Life Protection. Over the course of twenty-three years from 1919 to 1942, they lectured to "students" of all ages and led them on field trips. Bohumil Shimek considered the Wild Life School to be "unique," a place "which will develop the most lasting interest, making not only good conservationists of the participants, but making each one a bearer of light to his own community." 64

The second aspect that distinguished the movement in Iowa was a strong undercurrent of cooperation and coordination that kept ideas and activities flowing from the turn of the century through the 1930s. There were many who assumed leadership roles; the strength of the movement did not depend on the charisma of one individual. Pammel took the lead with state parks, but a loose "inner circle" of conservationists provided a certain level of cohesion and a sustained focus on broad objectives. Disagreements and disaffection never derailed the movement. Its vibrancy from the early twentieth century through the New Deal is remarkable; the record of achievements is impressive. By 1940, the list of accomplishments included a system of state and federal fisheries, land acquisitions for forest reserves, the nucleus of what would become the nation's largest wildlife and fish refuge, major contributions to conservation research in all areas, and one of the largest state park systems in the country. It is precisely because so many people were involved for so long that one can trace the evolution and transformation of conservation goals. Nowhere was that transformation more evident than in the state park system.

64. Bohumil Shimek to Fred G. Bell, 4 September 1923, Bohumil Shimek Papers, University of Iowa Archives. 
Copyright of Annals of Iowa is the property of State of Iowa, by \& through the State Historical Society of Iowa and its content may not be copied or emailed to multiple sites or posted to a listserv without the copyright holder's express written permission. However, users may print, download, or email articles for individual use. 